\title{
Accommodating Students with Disabilities: Professional Development Needs of Faculty
}

\section{Sheryl Burgstahler}

University of Washington

Faculy members play an important role in making academic programs accessible to postsecondary students with disabilities. However, instructors do not always possess the knowledge, experiences, and attitudes that result in the most inclusive environment for these students. A literature review was conducted to explore what faculty members need to know about accommodating students with disabilities in their courses and how they can best gain this knowledge. These results were used to develop a comprehensive set of training options that can be used with postsecondary instructors nationwide. The content of these options focuses on legal issues, accommodation strategies, and resources. Modes of instruction include on-site training, printed materials, distance learning, web-based self-paced instruction, and video presentations.

\section{INTRODUCTION}

Federal legislation has resulted in higher expectations and greater participa-

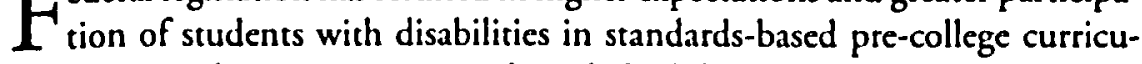
lum. As a result, more young people with disabilities are encouraged to pursue further learning, more are prepared to pursue postsecondary studies, and greater numbers of students with disabilities are attending postsecondary academic institutions (Gajar, 1998; Henderson, 2001; Horn \& Berktold, 1999; National Council on Disability, 2000).The largest and fastest growing subgroup of freshmen who report disabilities have learning disabilities- $40.4 \%$ in 2000 as compared to $16.1 \%$ in 1988 (Henderson, 2001). Percentages of 
students with disabilities who report other types of disabilities are $16.1 \%$ blindness or partial sight, $15.4 \%$ health-related impairments, $8.6 \%$ hearing impairments, $7.1 \%$ orthopedic impairments, $2.9 \%$ speech impairments, and 16.9\% other impairments (Henderson, 2001).

Students with disabilities who participate in postsecondary education are more likely to enroll in two-year community and technical colleges than are students without disabilities (Horn \& Berktold, 1999; National Council on Disability, 2000). Students with disabilities are less likely than their counterparts without disabilities to stay enrolled or to earn a postsecondary degree or credential. After five years, $53 \%$ of students with disabilities and $64 \%$ of those without disabilities have attained a degree or certificate or are still enrolled. Of these students, only $16 \%$ of those with disabilities, compared to $27 \%$ of those without disabilities, have attained a bachelor's degree (Horn $\&$ Berktold, 1999). Clearly, postsecondary educational outcomes are not as positive for students with disabilities as for those without disabilities.

Individuals with disabilities also find it difficult to secure and maintain employment (McNeil, 2000; National Council on Disability, 2000; Phelps \& Hanley-Maxwell, 1997). However, for people with disabilities, a postsecondary education is highly positively correlated with employment options and higher incomes. For individuals with disabilities there is actually a stronger positive correlation between level of education and rate of employment than for people without disabilities (Stodden, 1998). The employment rate is $16 \%$ for people with disabilities who have less than a high school diploma, $30 \%$ for those who have graduated from high school, $45 \%$ for those who have attended a college, and $50 \%$ for those who have at least four years of college (Yelin \& Katz, 1994).

The low employment rates for people with disabilities coupled with the positive impact of postsecondary education makes increasing the college success of this group an important goal. The cost of failure to provide accessible postsecondary education for people with disabilities, both to these individuals as well as to society, is significant (Blackorby \& Wagner, 1996; Gajar, 1998; National Council on Disability, 2000; Phelps \& Hanley-Maxwell, 1997; Reskin \& Roos, 1990; Stodden \& Dowrick, 2001; Wagner \& Blackorby, 1996).

\section{LEGAL IsSUES}

Section 504 of the Rehabilitation Act of 1973 prohibits discrimination against individuals with disabilities in programs and services that receive federal funds, which includes the vast majority of postsecondary institutions. The Americans with Disabilities Act (ADA) of 1990 reinforces and extends the 
requirements of Section 504 to public programs and services, regardless of whether they receive federal funds. For qualified students who disclose their disabilities and present appropriate documentation, postsecondary institutions must provide reasonable accommodations to assure equal access to program offerings (Frank \& Wade, 1993; McCusker, 1995; West, Kregel, Getzel, Zhu, Ipsen, \& Martin, 1993). These requirements apply to programs and services offered on the Internet as well (Patrick, 1996; Waddell, 1999). Court cases and complaints to the United States Department of Education Office of Civil Rights regarding the rights of postsecondary students with disabilities have continued to increase since the passage of the Rehabilitation Act. Students have challenged postsecondary decisions regarding requests for modifications to academic programs, changes in graduation requirements, and accommodations in specific courses (Dona \& Edmister, 2001). Dealing with the complaints and litigation that result when postsecondary institutions fail to provide reasonable accommodations to students with disabilities can be costly.

\section{Professional Development Needs of Faculty}

In order for students with disabilities to succeed in postsecondary education and for postsecondary institutions to meet their legal and ethical obligations, qualified people with disabilities must have equal access to educational programs, including those offered in classrooms, on field trips, in science labs, in computing facilities, and on the Internet. The success of these students depends upon their own efforts as well as those of campus support services and instructors (Frank \& Wade, 1993; National Center for the Study of Postsecondary Educational Supports, 2000a, 2000b; National Council on Disability, 2000). In particular, the willingness and ability of instructors to make reasonable accommodations in their courses can impact student achievement (Fonosch \& Schwab, 1981; Moore, Newlon, \& Nye, 1986).

Research suggests that many faculty members are generally willing to provide disability-related accommodations in their courses (Aksamit, Morris, \& Leuenberger, 1987; Hill, 1996; Houck, Asselin, Troutman, \& Arrington, 1992; Leyser, 1989; Leyser, Vogel, Wyland, \& Brulle, 1998; Nelson, Dodd, \& Smith, 1990). However, as a group, faculty have little or no training or experience in teaching students with disabilities and are often not fully aware of their legal obligations to provide access, of best practices for teaching students with disabilities, of computer and other technologies that increase academic and career options for people with disabilities, or of campus resources (Dodd, Fischer, Hermanson, \& Nelson, 1990; Dona \& Edmister, 2001; Leyser, 1989; Leyser et al., 1998; National Center for the Study of Postsecondary Educational 
Supports, 2000a, 2000b; Thompson, Bethea, \& Turner, 1997). Some faculty are concerned about maintaining academic integrity and confused about their roles and responsibilities in providing accommodations.

Some instructors have mistaken beliefs about the abilities of individuals with disabilities to succeed in academic studies and careers. Faulty assumptions are due, at least in part, to lack of knowledge about disabilities and of technological innovations that can contribute to their success in academics and careers, and to stereotypical negative images of people with disabilities in the media (Alexander \& Strain, 1978; Anderson-Inman, Knox-Quinn, \& Szymanski, 1999; Blackhurst, Lahm, Harrision, \& Chandler, 1999; Hannah \& Pliner, 1983; Jamieson, 1984; Yuker, 1994). Faculty attitudes influence behavior toward students that, in turn, affects both student self-image and academic performance (Alexander \& Strain, 1978). Prejudicial treatment creates obstacles for students with disabilities in higher education that can be more disabling than their physical or cognitive impairments.

Faculty attitudes about students with disabilities have been found to be related to academic discipline. For example, education, social science, and business faculty have been found to be among those more willing to accommodate students with disabilities, while science faculty are among those who are less willing (Fonosch \& Schwab, 1981; Nelson, Dodd, \& Smith, 1990). Some instructors feel that students with certain types of disabilities do not belong in their fields of study.

Many instructors support the integration of students with sensory and physical disabilities in higher education but are less supportive of integrating students with learning disabilities and social/psychological/emotional disabilities (Burgstahler, Duclos, \& Turcotte, 1999; Hannah \& Pliner, 1983; Leyser, 1989; Matthews, Anderson, \& Skolnick, 1987; Minner \& Prater, 1984). There is ongoing debate about how to honor both the rights of students with disabilities to receive "reasonable" accommodations and the rights of academic programs to maintain academic standards. Faculty members are more willing to implement accommodations that are easy to provide, require little extra time, and facilitate the integration of students into the planned course activities. They are less willing to provide accommodations that they perceive will lower course standards or give unfair advantage to some students, such as overlooking misspellings, allowing substitutions for courses, providing alternative assignments, and providing copies of lecture notes (Leyser, 1989; Leyser ct al., 1998; Nelson, Dodd, \& Smith 1990).

Some instructors feel uncomfortable talking to students with disabilitics. Faculty members with more experience with and knowledge about students 
with disabilities, however, are more comfortable working with these students than those with less experience and knowledge (Aksamit, Leuenberger, \& Morris, 1987; Fichten, Amsel, Bourdon, \& Creti, 1988; Fonosch \& Schwab, 1981).

Reports of negative experiences with faculty members by students with disabilities are not widespread. However, some students report that faculty members project negative attitudes and lack of knowledge about accommodations. Others report having difficulty acquiring needed academic accommodations, especially for learning and other disabilities that are not obvious, and maintaining confidentiality of disability-related information (Burgstahler, Duclos, \& Turcotte, 1999; Hill, 1996; National Center for the Study of Postsecondary Educational Supports, 2000b). Students with disabilities are sometimes reluctant to ask for accommodations because of their concerns that instructors might have negative attitudes about them and may not respect their privacy (Burgstahler, Duclos, \& Turcotte, 1999; Moore, Newlon, \& Nye, 1986; National Center on the Study of Postsecondary Educational Supports, 2000b).

Both faculty and students express the need for faculty members to increase their knowledge and understanding of legal obligations to provide academic accommodations, typical accommodation strategies, and available resources (Burgstahler, Duclos, \& Turcotte, 1999; Leyser et al., 1998; National Center on the Study of Postsecondary Educational Supports, 2000b). The role that assistive technology can play in accommodating students with disabilities as well as steps instructors can take to make their information resources (e.g., web pages) accessible has also been suggested as relevant content (Fichten, Barile, \& Asuncion, 1999). In addition, faculty members could use guidance on how to more effectively communicate with students who have disabilities about the impact of their disabilities and accommodation issues.

Overall, faculty members and administrators are receptive to receiving training in these areas (Nelson, Dodd, \& Smith, 1990; Leyser et al., 1998). They report a desire for multiple presentation delivery methods, including short printed publications, Internet-based resources, and in-person short presentations (Burgstahler et al., 1999; Leyser et al., 1998).

\section{Research into Practice}

Legal mandates, poor postsecondary employment outcomes for people with disabilities, and a positive correlation between college participation and career success combine to make it critically important that postsecondary programs are accessible to students with disabilities. Since faculty members play a central 
role in the learning of all students, yet have limited knowledge and experience in accommodating students with disabilities, professional development for this group has the potential to improve the postsecondary academic and career outcomes for students with disabilities (Caffarella \& Zinn, 1999). Training at two-year colleges is especially important because of the greater numbers of students with disabilities who attend these schools when compared to the numbers who attend four-year institutions (Horn \& Berktold, 1999; National Council on Disability, 2000).

On many campuses, staff from disabled student services programs are in the best position to take the lead in delivering programs to help faculty and administrators more fully include students with disabilities in their courses. Trainers who cultivate a rich, interactive dialogue as well as develop an ongoing relationship with faculty can go a long way toward creating positive attitudes about accommodating these students. To develop the most appropriate training options, staff from the disabled student services office can collaborate with faculty from specific academic departments, as well as staff with specialized expertise from computing centers and other campus support services. Learning about the experiences of students with disabilities on campus in general and within specific departments can also help to assure that training content is relevant.

Proven practices in teaching the adult learner can provide general guidance as professional development options for faculty are being developed. This field of study suggests that trainers develop content that is relevant and useful to members of the audience; involve participants in both the development and the learning process; understand the adult need for self-directed learning; respect participant expertise in their fields; provide opportunities for participants to share insights, experiences, and information; and recognize the group's wide range in knowledge, experiences, and learning styles (Addison, 1978; Brookfield, 1993; Claxton \& Ralston, 1978; Conti, 1998; Grasha, 1984; Knowles, 1980; Pierce, 1998; Thomas, 1991; Tight, 1981; Wooldridge, 1995; Yuker, 1994).

Specifically, on-site instruction about working with students who have disabilities should include opportunities for faculty participants to be engaged in learning, to share experiences and concerns in working with students who have disabilities, to learn from their peers, and to address specific questions. Faculty participants should be allowed to openly discuss fears, issues, and concerns. Strategies and materials used should address the diversity of learning needs represented in the audience. Some instructors are eager to learn about disability-related issues; others may define their interest as the minimum 
amount of information they need to perform their jobs; all participants have time constraints. Trainers should model an attitude of respect for the rights and responsibilities of the institution, students with disabilities, and faculty members.

Faculty development options can address the need expressed by faculty for information about disability-related accommodations, legal issues, and resources. It is also important to provide guidance about how to best communicate with students who have disabilities and how to preserve the confidentiality of disability-related information. Faculty training on disability issues can serve to dismiss incorrect perceptions regarding legal responsibilities and capabilities of people with disabilities. Carefully designed materials and strategies can offer faculty members practical strategies and meaningful discussion about disability issues. Trainers should emphasize that academic accommodations do not need to be elaborate; creativity and common sense can lead to practical measures that assure access. Special training opportunities regarding accommodating students with learning disabilities should be made available since the largest group of students with disabilities is composed of those with learning disabilities. Disabilities of this type are especially challenging for faculty members to understand and accommodate (Houck, Asselin, Troutman, \& Arrington, 1992; Vogel, Leyser, Wyland, \& Brulle, 1999).

Faculty development opportunities can help make instructors more comfortable with their role in providing a learning environment which, for all students, provides full access to the content and activities they offer, yet does not give unfair advantage to one group. Helping instructors make a paradigm shift from a sole focus on special accommodations for students with disabilities to employment of universal design principles as they develop instructional strategies in their courses may make them more responsive to the needs of learners with a wide range of characteristics. In contrast to considering only the average or typical student when course materials and strategies are developed, this approach requires that instructors consider the wide variety of characteristics of students who might enroll in their courses, including those with disabilities, for the purpose of creating more inclusive on-site and electronic learning environments (Bowe, 2000; Burgstahler, 2000).

Professional development tailored to specific academic units can include examples of accommodations typical in those fields of study. Specifically, training for faculty members in academic areas where advancing technology increases opportunities for the participation of students with disabilities can correct faulty assumptions about what students with disabilities can accomplish and clarify the availability of campus resources. For example, disabled 
students service staff might co-present with staff from the campus computing services organization to offer professional development to faculty members in information technology fields. Participants could be made aware of assistive technology that allows individuals with a wide range of disabilities to access computers and other electronic devices, as long as web pages and other electronic resources are designed in accessible formats. Instruction on how to purchase and create electronic products that are accessible to individuals with disabilities could also be included in the presentation.

Key information needed by faculty members and administrators should be provided in a variety of formats and venues in order to address differences in faculty learning styles and preferences, time constraints, schedules, knowledge and experiences, and desire for information. Besides on-site presentations, printed, web-based, and videotaped options should be explored. Assuring that follow-up, case-specific support is readily available as needs arise can serve to lower the level of concern of faculty members and reduce the time needed to provide effective accommodations.

\section{The DO-IT Model Demonstration Project}

DO-IT (Disabilities, Opportunities, Internetworking, and Technology), at the University of Washington, developed a set of professional development options for postsecondary faculty to increase their knowledge and skills in supporting students with disabilities. The curriculum was developed and delivered through a team of instructors and administrators from 23 postsecondary institutions nationwide. Each team member adopted a partner school with demographics different than their own, resulting in a group of 23 twoyear and technical colleges and 23 four-year schools overall. A survey of the literature and the collective experiences of team members informed the development of all project products and strategies.

The DO-IT Prof project team created a short publication that can be modified for use on any campus (www.washington.edu/doit/Brochures/Acade mics/teachers.html). It summarizes the content of most interest to faculty members and administrators-legal issues, accommodation strategies, and campus resources. It also includes a sample statement that can be put on a syllabus to encourage students with disabilitics to make an appointment to discuss disability-related accommodations with the instructor. Responding to the diverse content and scheduling needs and delivery options reported by faculty and administrators, the DO-IT Prof project created six models of professional development. All delivery options focus on typical academic accommodations for students with disabilities, legal issues, and campus resources. They also deal 
with ways to communicate with students with disabilities as well as assure confidentiality of disability-related information. Professional development options are adaptable and can be tailored to the individual needs of faculty members, as part of regular departmental meetings or as separate presentations.

The six models of professional development, along with evaluative data from participants, are described below (DO-IT, 2001a). Models 1, 2, and 3 are on-site presentations.

Model 1. This 20- to 30-minute presentation is designed to be delivered to faculty and administrators at regular departmental meetings to introduce participants to basic legal issues, accommodation strategies, and campus resources. The cooperative relationship between students and instructors is emphasized. An eight-minute videotape, Working Together: Faculty and Students with Disabilities, (DO-IT, 2001b) may be incorporated into this short presentation.

Model 2. One- to two-hour presentations focus on accommodation strategies for students with disabilities, legal issues, and campus resources. The cooperative relationship between the student, the instructor, and the campus office that supports students with disabilities is emphasized in the videotape Building the Team: Faculty, Staff and Students Working Together(DO-IT, 2001c).

Model 3. A series of tailored presentations were developed by the DO-IT Prof project. Topics were chosen in response to professional development needs expressed by faculty members and administrators. For example, one training topic deals with accommodating students who have learning disabilities, the largest group of students with disabilities on postsecondary campuses and the one for which faculty members report the most confusion and concern. One tailored training module shows educators how to make their web pages accessible to students with disabilities and another teaches them how to develop accessible distance learning courses.

In total, DO-IT Prof Models 1, 2, and 3 have been presented to more than 5,000 faculty members and administrators in postsecondary institutions nationwide. Short printed materials have been distributed at most of the presentations. The results from a sample of 878 surveys completed by participants suggest that faculty members and administrators who participate in these training options have a greater understanding of their legal obligations, feel better prepared to accommodate students with disabilities in their classes, and are more aware of campus resources. Respondents indicated what they learned by rating their level of agreement with statements made about the content of presentations on a scale of 1 to 5 where 1 = strongly disagree and $5=$ strongly agrec. Overall, participants agreed that as a result of the presentations, they were better able to find resources on their campuses to accommodate students 
with disabilities (mean $=4.46$ ), and that they gained knowledge about legal obligations (mean $=4.72$ ), specific accommodations (mean $=4.76$ ), and technology available (mean $=4.46$ ) to support students with disabilities (DO-IT, 2001). Personal reactions to the on-site training were also very positive. They include:

- "[I learned] tape recorders are available to students with disabilities as an accommodation in the classroom." (faculty)

- "The accommodations in the classroom were useful because [they] helped me to understand the procedure and how to accommodate the student." (faculty)

- "[I learned] specific parameters of college/university obligations to provide accommodations." (faculty)

- "This was the tip of the iceberg. I'd like more in-depth seminars to follow." (teaching assistant)

Model 4. The DO-IT Prof project has made available to faculty self-paced, online instruction with comprehensive content that is tailored to faculty interests and needs. In addition, downloadable multimedia presentations and extensive lists of references and links to other useful web sites are available at the Faculty Room web site (www.washington.edu/doit/Faculty). This material is tailored specifically to postsecondary faculty and administrators. "The great strength of The Faculty Room concept lies in its quick and almost universal accessibility," according to John Pedraza, disabilities resource coordinator at Michigan State University (MSU). "The Faculty Room is a great site for faculty to learn more about students with disabilities at their own pace when they have immediate questions to be answered," Pedraza said. "MSU faculty find it extremely useful." Other reactions to this resource include:

- "[I learned] the DSS [Disabled Student Services] office is a resource for me as well as the student." (administrator)

- "I learned a lot about the technology that is available." (faculty member)

- "All the information was very informative! Thanks for the web site resources." (instructional designer)

- "I was really impressed with the system available on campus." (teaching assistant) 
Responses to the question, Which parts of The Faculty Room were the most useful to you and why? included:

- "Overall descriptions and case studies because I could use them as links to our database!"

- "The case studies/FAQ's-but all of it really. I came across this web site today via a listserv I belong to, and so far I think it is a gold mine. It's very clearly presented and all useful information. I'm glad I found it."

- "I loved accessing it as it could be linked with our work! Perfect collaboration!"

- "I like that it's easy, convenient, that I can bookmark it, and go back to it when I need to-especially the case studies. There's nothing I really dislike..."

- "I am the disability services person at my school and I am very impressed with this site. I am considering notifying all the faculty about it via email so they can link up to it as needed."

- "Super resource. Please keep it going and do not change any of the URLs as you are firmly linked into our Learning and Teaching links throughout the database!! :>))."

Model 5. A distance any time, any where course provides lessons and discussion delivered via electronic mail. The lessons for this distance learning course can be obtained in the Faculty Room at www.washington.edu/doit/ Faculty/Presentations/Distance/. They can by easily tailored to and delivered on any postsecondary campus, perhaps as part of orientations for new faculty.

Model 6 . The televised instruction option uses a series of training videotapes to deliver professional development on public television stations hosted by institutions of higher education nationwide. As with the other models of instructional delivery, these tapes were developed in response to interests and needs expressed by faculty members and administrators. Videotaped presentations are downloadable from the Faculty Room and videotapes can be purchased from DO-IT.

\section{Conclusion}

Whether conscious or unconscious, the prejudicial attitudes and lack of knowledge and skills on the part of instructors may create barriers to the pursuit of educational opportunities for students with disabilities. Full access 
to postsecondary programs can be promoted through the increased knowledge and skills of all stakeholders and better coordination among faculty and support services. Ultimately, increased knowledge and skills of instructors regarding legal issues, accommodations, and resources can lead to more positive postsecondary and career outcomes for students with disabilities.

\section{RefERENCES}

Addison, W. (1978). Helping others learn: Designing programs for adults. Reading, MA: McLagan.

Aksamit, D., Morris, M., \& Leuenberger, J. (1987). Preparation of student services professionals and faculty for serving learning-disabled college students. Journal of College Student Personnel, 28, 53-59.

Alexander, C., \& Strain, P. (1978). A review of educator's attitudes toward handicapped children and the concept of mainstreaming. Psychology in the Schools, 15, $390-396$.

Anderson-Inman, L., Knox-Quinn, C., \& Szymanski, M. (1999). Computer-supported studying: Stories of successful transition to postsecondary education. $C_{a}$ reer Development for Exceptional Individuals, 22 (2), 185-212.

Blackhurst, A. E., Lahm, E. A., Harrison, E. M., \& Chandler, W. G. (1999). A framework for aligning technology with transition competencies. Career Development for Exceptional Individuals, 22 (2), 131-151.

Blackorby, J., \& Wagner, M. (1996). Longitudinal post-school outcomes of youth with disabilities: Findings from the national longitudinal transition study. Exceptional Children, 62 (5), 399-413.

Bowe, F. G. (2000). Universal design in education: Teaching nontraditional students. Westport, CT: Bergin \& Garvey.

Brookfield, S. D. (1993). Self-directed learning, political clarity and the critical practice of adult education. Adult Education Quarterly, 43 (4), 227-242.

Burgstahler, S. (2000). Universal design of instruction. Seattle, WA: University of Washington, DO-IT.

Burgstahler, S., Duclos, R., \& Turcotte, M. (1999). Preliminary findings: Faculty, teaching assistant, and student perceptions regarding accommodating students with disabilities in postsecondary environments. Seattle, WA: University of Washington, DO-IT. 
Caffarella, S., \& Zinn, L. (1999). Professional development for faculty in higher education: A conceptual framework of barriers and supports. Innovative Higher Education, 23 (3), 241-254.

Claxton, C. S., \& Ralston, Y. (1978). Learning styles: Their impact on teaching and administration. Washington, DC: American Association for Higher Education.

Conti, G. J. (1998). Identifying your teaching style. In M. W. Galbraith (Ed.), Adult learning methods (pp. 73-77). Malabar, FL: Kreiger.

Dodd, J. M., Fischer, J., Hermanson, M., \& Nelson, J. R. (1990). Tribal college faculty willingness to provide accommodations to students with learning disabilities. Journal of American Indian Education, 30 (1), 8-16.

DO-IT. (20012). DO-IT Prof Annual Report. Seattle, WA: University of Washington, DO-IT.

DO-IT, University of Washington (Producer), \& Burgstahler, S. (Director). (2001b). Building the team: Faculty, staff, and students working together [Videotape]. Seattle, WA: University of Washington, DO-IT.

DO-IT, University of Washington (Producer), \& Burgstahler, S. (Director). (2001c). Working together: Faculty and students with disabilities [Videotape]. Seattle, WA: University of Washington, DO-IT.

Dona, J., \& Edmister, J. H. (2001). An examination of community college faculty members' knowledge of the Americans with Disabilities Act of 1990 at the fifteen community colleges in Mississippi. Journal of Postsecondary Education and Disability, 14(2), 91-103.

Fichten, C. S., Amsel, R., Bourdon, C. V., \& Creti, L. (1988). Interaction between college students with a physical disability and their professors. Journal of Applied Rechabilitation Counseling, 19, 13-21.

Fichten, C., Barile, M., \& Asuncion, J. V. (1999). Learning technologies: Students with disabilities in posssecondary education. Office of Learning Technologies. Montreal, Canada: Dawson College, Adaprech Project.

Fonosch, G. G., \& Schwab, L. O. (1981). Attitudes of selected university faculty members toward disabled students. Journal of College Student Personnel, 22, 229-235.

Frank, K., \& Wade, P. (1993). Disabled student services in postsecondary education: Who's responsible for what? Journal of College Student Development, 34(1), 26-30.

Gajar. A. (1998). Postsecondary education. In F. Rusch \& J. Chadsey (Eds.), Beyond bigh school: Transision from school to work (pp. 383-405). Belmont, CA: Wadsworth. 
Grasha, A. (1984). Learning styles: The journey from Greenwich Observatory to the college classroom. Improving College and University Teaching, 22, 46-53.

Hannah, M., \& Pliner, S. (1983). Teacher attitudes toward handicapped children: A review and synthesis. School Psychology Review, 12, 12-25.

Henderson, C. (2001). College freshmen with disabilities: A biennial statistical profile. Washington, DC: American Council on Education.

Hill, J. L. (1996). Speaking out: Perceptions of students with disabilitics regarding adequacy of services and willingness of faculty to make accommodations. Journal of Postsecondary Education and Disability, 12(1), 22-43.

Horn, L., \& Berktold, J. (1999). Srudents with disabilities in postsecondary education: A profile of preparation, participation, and outcomes. Education Statistics Quarterly, 1(3), 59-64.

Houck, C., Asselin, S., Troutman, G., \& Arrington, J. (1992). Students with learning disabilities in the university environment: $A$ study of faculty and student perceptions. Journal of Learning Disabilities, 25 (10), 678-684.

Jamieson, J. (1984). Attitudes of educators toward the handicapped. In R. Jones (Ed.), Attitudes and attitude change in special education: Theory and practice (pp. 206-222). Arlington, VA: The Council for Exceptional Children.

Knowles, M. S. (1980). The modern practice of adult education: From pedagogy to andragogy. New York, NY: Cambridge Books.

Leyser, Y. (1989). A survey of faculty attitudes and accommodations for students with disabilities. Journal of Postsecondary Education and Disability, 7(3 \& 4), 97-108.

Leyser, Y., Vogel, S., Wyland, S., \& Brulle, A. (1998). Faculty attitudes and practices regarding students with disabilities: Two decades after implementation of Section 504. Journal of Postsecondary Education and Disability, 13 (3), 5-19.

Matthews, P., Anderson, D., \& Skolnick, B. (1 987). Faculty attitudes toward accommodations for college students with learning disabilities. Learning Disabilities Focus, 3, 46-52.

McCusker, C. (1995). The Americans with Disabilities Acr: Its potential for expanding the scope of reasonable academic accommodations. Journal of College and University Law, 21 (4), 619-641.

McNeil, J. M. (2000). Employmenc, earnings, and disability. Prepared for the 75th annual Conference of the Western Economic Association International, Vancouver, Canada.

Minner, S., \& Prater, G. (1984). College teachers' expectations of LD students. Academic Therapy, 20(2), 225-25). 
Moore, C. J., Newlon, B. J., \& Nye, N. (1986). Faculty awareness of needs of physically disabled students in the college classroom. Bulletin of the Association on Handicapped Student Services Programs in Postsecondary Education, 4, 137-1 45.

National Center for the Study of Postsecondary Educational Supports (NCSPES). (2000a). National survey of educational support provision to students with disabilities in postsecondary education settings. Honolulu, HI: University of Hawaii at Manoa.

National Center for the Study of Postsecondary Educational Supports (NCSPES). (2000b). Posssecondary education and employment for students with disabilities: Focus group discussions on supports and barriers in lifelong learning. Honolulu, $\mathrm{HI}$ : University of Hawaii at Manoa.

National Council on Disability. (2000). Transition and post-school outcomes for youth with disabilities: Closing the gaps to post-secondary education and employment. Washington, DC: Author.

Nelson, J., Dodd, J., \& Smith, D. (1990). Faculty willingness to accommodate students with learning disabilities: A comparison among academic divisions. Journal of Learning Disabilities, 23(3), 185-189.

Patrick, D. L. (1996). Correspondence to Senator Tom Harkin, September 9, 1996. Retrieved March 16, 2002 from www.usdoj.gov/crt/foia/cltr204.txt

Phelps, L. A., \& Hanlcy-Maxwell, C. (1997). School-to-work transitions for youth with disabilities: A review of outcomes and practices. Review of Educational Research, 67(2), 197-226.

Pierce, G. (1998, Spring). Teaching teachers: A model for the professional development of new faculty. Adult Learning, 17-20.

Reskin, B., \& Roos, P. (1990). Job queues. Gender queues. Philadelphia, PA: Temple University Press.

Schmetzke, A. (2001) Online distance education: 'Anytime, anywhere' but not for everyone. Information Technology and Disability Jourmal 7 (2). Available hetp://www.rit.edu/-easi/itd/itdv07n2/axel.htm

Stodden, R. A. (1998). School-to-work transition: Overview of disability legislation. In F. Rusch \& J. Chadscy (Eds.), Beyond high school: Transition from school to work: Belmont, CA: Wadsworth Publishing.

Stodden, R. A., \& Dowrick, P. W. (2001). Postsecondary education and employment of adults with disabilities. American Rebabilitation, 25 (3), 19-23.

Thomas, A. M. (1991). Beyond education: A new perspective on society's management of learning. San Francisco, CA: Josscy-Bass. 
Thompson, A., Bethea, L., \& Turner, J. (1997). Faculty knowledge of disability laws in high education: A survey. Rebabilitation Counseling Bulletin, 40, 166-180.

Tight, M. (Ed.). (1981). Adult learning and education. Kent, England: Croom Helm.

Vogel, S., Leyser, Y., Wyland, S., \& Brulle, A. (1999). Students with learning disabilities in higher education: Faculty attitude and practices. Learning Disabilities Research \& Practice, 14(3), 173-186.

Waddell, C. D. (1999). The growing digital divide in access for people with disabilities: Overcoming barriers to participation in the digital economy. Retrieved from http://www.icdri.org/the_digital_divide.htm

Wagner, M., \& Blackorby, J. (1996). Transition from high school to work or college: How special education students fare. The future of children: Special education for students with disabilities, 6(1), 103-120.

West, M., Kregel, J., Getzel, E., Zhu, M., Ipsen, S., \& Martin, E. (1993). Beyond Scction 504: Satisfaction and empowerment of students with disabilities in higher education. Exceptional Children, 59(5), 456-467.

Wooldridge, B. (1995). Increasing the effectiveness of university/college instruction: Integrating the results of learning style research into course design and delivery. In R. R. Sims \& S. J. Sims (Eds.), The importance of learning styles (pp. 49-68). Westport, CT: Greenwood.

Yelin, E., \& Katz, P. (1994). Labor force trends of persons with and without disabilities. Monthly Labor Review, 117, 36-42.

Yuker, H. (1994). Variables that influence attitudes toward people with disabilities. Psychosocial Perspectives on Disability, 9(5), 3-22.

\section{ACKNOWLEDGMENTS}

This chapter is based upon work supported by the National Science Foundation (grant \#9800324) and the United States Department of Education, Office of Postsecondary Education (grant \#P33A990042). Any opinions, findings, and conclusions or recommendations expressed in this material are those of the author and do not necessarily reflect the views of federal government. 


\section{Contact:}

Sheryl Burgstahler

Director, DO-IT

454515 th Avenue NE, Room 109

University of Washington

Seattle, WA $98105-4527$

Voice (206) 543-0622

Fax (206) 685-4054

Email sherylb@cac.washington.edu

Sheryl Burgstahler directs project DO-IT (Disabilities, Opportunities, Internetworking, and Technology) at the University of Washington. Dr. Burgstahler also codirects the National Center on Accessible Information in Education (AccessIT) to promote the use of accessible technology in educational setrings. She has published dozens of articles and delivered presentations at national and international conferences that focus on the full inclusion of individuals with disabilities in postsecondary education, distance learning, work-based learning, and electronic communities, and is the author or co-author of six books on using the Internet with pre-college students. She is Assistant Director of Information Systems and Affliate Associare Professor in Education at the University of Washington. 